\title{
Acute Toxicity Study of the Combination of Azadirachta indica A. Juss. and Gynura procumbens (Lour.) Merr. Leave Extracts
}

\author{
Nofran Putra Pratama ${ }^{*}$, Kurnia Rahayu Purnomo Sari; Ririn Irma Marliana \\ Faculty of Health, Universitas Jenderal Achmad Yani Yogyakarta, Jl. Ringroad Barat, Gamping Kidul, Ambarketawang, Gamping, Sleman, \\ Yogyakarta 55294 .
}

\begin{abstract}
Azadirachta indica A.Juss. and Gynura procumbens (Merr.) are medicinal herbs widely used in traditional medicine. Recent research on the combination of these two plants showed aggressive antioxidant activity. The combination results can improve insulin and beta-cell morphology and can increase insulin expression. The variety of activities performed is the basis for conducting acute toxicity tests on the ethanol extract of Azadirachta Indica A. Juss. and Gynura procumbens (Lour.) Merr. to increase public confidence in its efficacy and ensure the safety of its use. The acute toxicity test on the ethanol extract of Azadirachta Indica A. Juss. and Gynura procumbens (Lour.) Merr. was carried out on female Wistar rats by following the 423 procedures of OECD (Organization for Economic Cooperation and Development) Guideline with five groups of experimental animals, namely normal treatment, aquadest solvent treatment and $0.5 \mathrm{Na}$ CMC $0.5 \%$, a separate treatment of the ethanol extract of Azadirachta Indica A. Juss., a separate treatment of the ethanol extract of Gynura procumbens (Lour.) Merr., and combination treatment of the ethanol extract of Azadirachta Indica A. Juss. and leaves of Gynura procumbens (Lour.) Merr. Furthermore, it was proceeded by observing the liver of the experimental animals histopathologically. The acute toxicity test results utilizing the 423 procedures of the OECD did not confirm any death or signs of toxicity in the experimental animals, and histopathological observations did not show any major histopathological damage. Based on these results, according to Globally Harmonized Classification System (GHS), the combination of the ethanol extract of Azadirachta Indica A. Juss. and Gynura procumbens (Lour.) Merr. is included in the unclassified category (> 2,000 $\mathrm{mg} / \mathrm{kg} \mathrm{BW}$.
\end{abstract}

Keywords: Acute toxicity; Azadirachta Indica A. Juss. and Gynura procumbens (Lour.) Merr; Histopathology; OECD

\footnotetext{
*Corresponding author, e-mail: nofranputrapratama@gmail.com
}

\section{Data of article}

Received : 21 Nov 2020

Reviewed : 12 Dec 2020

Accepted : 22 Feb 2021

DOI

10.18196/jfaps.v1i2.9868

Type of article:

Research 


\section{INTRODUCTION}

The use of natural materials, especially those derived from plant materials, has been carried out by the Indonesian people from generation to generation to prevent and treat diseases. This natural ingredient is known as traditional medicine/herbs as its manufacture, and use principles are still traditional, and most of its properties to date have merely been based on empirical experience. The use of traditional medicine is considered an alternative treatment with few side effects. Therefore, further research is required on the safety testing of these traditional medicines/herbs. Research related to traditional medicines/herbs derived from plants is still mainly in the form of separated extracts, while the combined extracts are still rarely conducted. The combined extracts can be an alternative in the development of medicinal plants to obtain better results.

One example of a combination of extracts that has been widely researched is the combination of the ethanol extract of Azadirachta Indica A. Juss. and Gynura procumbens (Lour.) Merr. having been known to have many properties, including antioxidant activity ${ }^{1}$, decreased blood glucose levels ${ }^{2}$, decreased glycemia and improving insulin morphology and beta cells and increasing insulin expression ${ }^{3}$, significantly decreased glycemia in streptozotocin-induced rats $^{4}$, and hypoglycemic effect in mice ${ }^{5}$.

An acute toxicity test is needed to determine the safety of the combination of the ethanol extract of Azadirachta Indica A. Juss. and Gynura procumbens (Lour.) Merr. This test is intended to obtain information regarding the symptoms of poisoning, the cause of death, the sequence of the death process, and the lethal dose range for the experimental animals (LD50) 6 . Based on the data above, an acute toxicity test was carried out utilizing a method adopted from the Organization for Economic Co-operation and Development (OECD) and histopathological observation on the lab rats' liver.

\section{METHODS}

\section{Materials}

The materials for the extract of Azadirachta Indica A. Juss. and Gynura procumbens (Lour.) Merr. were obtained from Moyudan Sleman Yogyakarta, such as $70 \%$ ethanol (Onemed). CMC Na 0.5\%, buffer formalin $10 \%, \mathrm{NaCl}$ physiology (Otsuka), Hematoxillin Eosin (Merck) 1 , female Wistar rats.

\section{Research Process}

\section{Animal grouping}

An acute toxicity test of a combination of the ethanol extract of Azadirachta Indica A. Juss. and Gynura procumbens (Lour.) Merr. utilized the 423 procedures of OECD guidelines ${ }^{7}$. The experimental animals handled were 15 female Wistar rats aged 8-12 weeks, not pregnant, with a bodyweight of 150-250 grams. Female experimental animals were more sensitive than males, allowing toxic effects to appear in female animals.

The experimental animals were divided into five groups, consisting of 3 animals in each group. The control groups (without treatment) were the solvent control group (aquades and $0.5 \% \mathrm{Na}$ $\mathrm{CMC}$ ), the group of the ethanol extract of Azadirachta Indica A. Juss., the group 
of the ethanol extract of Gynura procumbens (Lour.) Merr, and the group of the combined extract of both.

\section{Provision of test preparation}

In the first stage of the test, the experimental animals were fasted overnight before administrating the test preparation, and its weighed. After that, the pressure was carried out on three experimental animals with an initial $300 \mathrm{mg} / \mathrm{kg} \mathrm{BW}$ dose. Furthermore, the toxic symptoms were observed, especially during the first 4 hours, and were continued during the first 24 hours after the treatment. Observation of toxic symptoms was continued every day until the 14 th day. When 2-3 experimental animals died, the dose was reduced to $50 \mathrm{mg} / \mathrm{Kg} \mathrm{BB}$.

Meanwhile, when 0-1 experimental animals died, administration of test preparations of $300 \mathrm{mg} / \mathrm{Kg}$ BW was continued. When 0-1 experimental animals died in the second round, the test was continued by administering a test dosage of $2000 \mathrm{mg} / \mathrm{Kg} \mathrm{BB}$ to 3 test animals, as shown in Figure 1 . The weight of the experimental animals was weighed on day $1,2,5,8,11,14$. On the 14th day, the tested animals were dynecropsied, and a histopathological examination was performed.

\section{Observation of toxic symptoms}

The physical observation was carried out on toxic symptoms in all rats from the five test groups. This examination was carried out continuously during the first four hours after giving the test preparation. Observation of toxic symptoms qualitatively followed the criteria in the Balazs table ${ }^{8}$.

However, not all criteria in the Balazs table were observed in this study. The criteria observed were those that could be seen with the naked eye, such as changes in behavior, body weight, seizures, tremors, paralysis, sedation, coma, and salivation.

\section{Histopathological observations}

Histopathological observations were carried out in several stages, namely organ harvesting, making histopathological preparations carried out at Balai Besar Veteriner Yogyakarta, and histopathological examinations by comparing them with the organ's histological preparations and histology of the treated groups of experimental animals qualitatively.

\section{RESULTS AND DISCUSSION}

Data on experimental animals' body weight were used to determine whether the extract treatment affected the experimental animals' weight. In addition, one of the symptoms of toxicity can be weight loss ${ }^{8}$. Based on the results of body weight observations, a graph of the experimental animal weight's average was created to illustrate the experimental animals' changes in body weight for 14 days (Figures 1 and 2). 


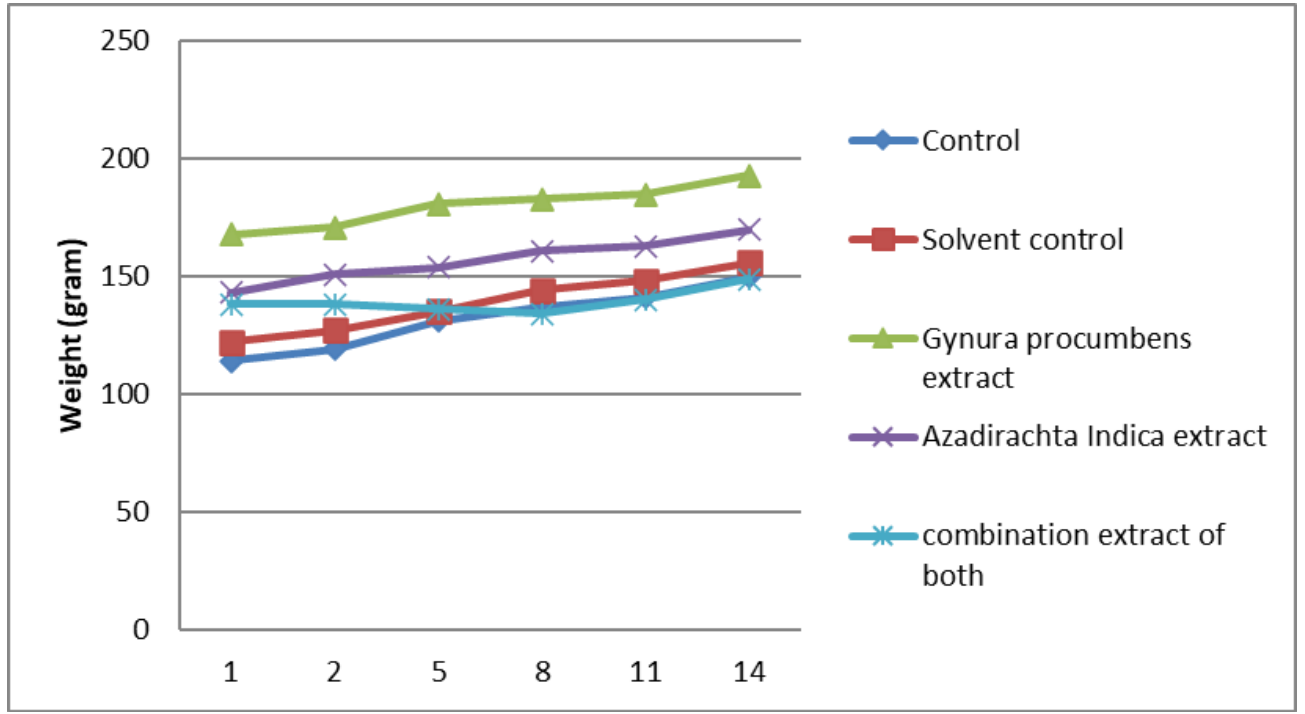

Figure 1. A graph of the average weight of the experimental animal after the administration of test preparation of $300 \mathrm{mg} / \mathrm{kg} \mathrm{BW}$ for 14 days of observation.

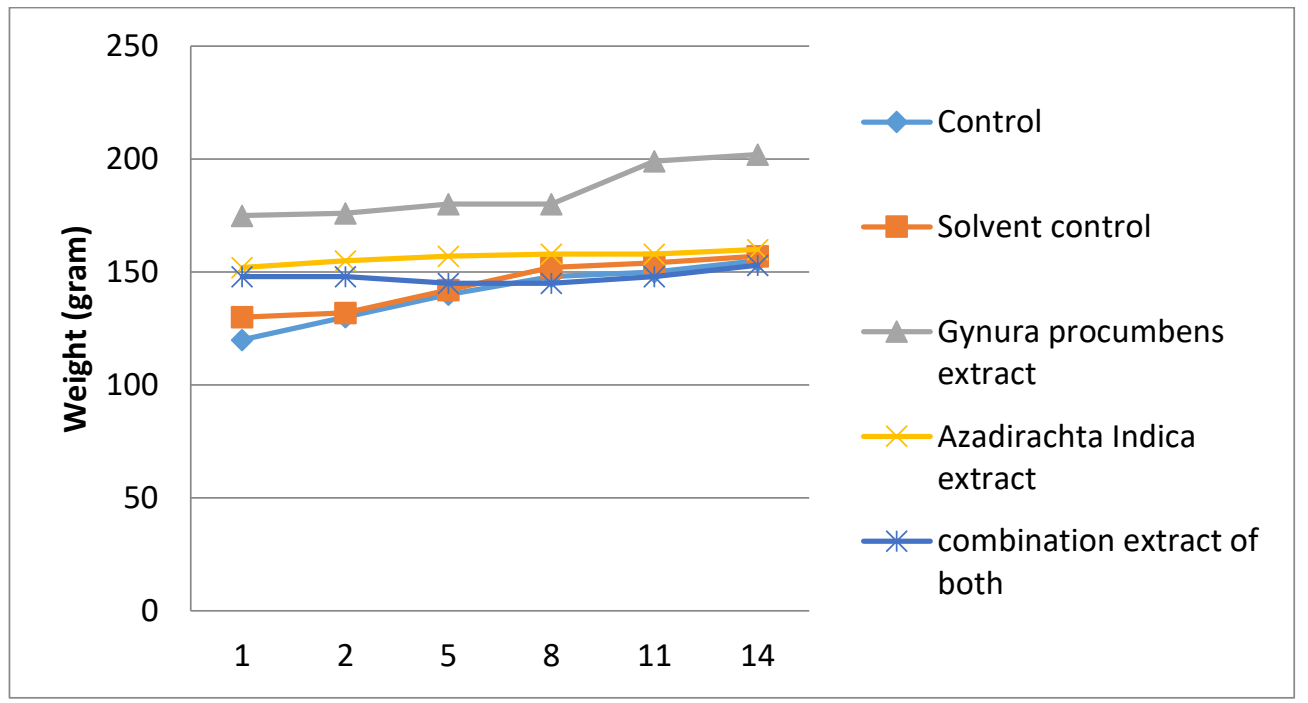

Figure 2. A graph of the average weight of the experimental animal after the administration of test preparation of $2,000 \mathrm{mg} / \mathrm{kg} \mathrm{BW}$ for 14 days of observation

Based on the experiment's weight average figure after administrating the test preparation, there was no decrease in the experimental animals' weight. It indicates one of the toxic symptoms, namely weight loss, was not found. The difference in weight between each treatment might be due to each experimental animal's amount of food consumed. The amount of food consumed was different as the amount of feed given was not weighted.
Dosage for the Azadirachta Indica A. Juss test was $50 \mathrm{mg} / \mathrm{kg} \mathrm{BW}$ and $112.5 \mathrm{mg} / \mathrm{kg}$ BW was Gynura procumbens (Lour.) Merr3. For the essential dosage of acute toxicity, the selection of the dosage was carried out based on the 423 procedures of OECD Guideline consisting of dosages of 5,50 , 300 , and $2,000 \mathrm{mg} / \mathrm{kg} \mathrm{BW}$, as well as additional tests with a dose of $5.000 \mathrm{mg} / \mathrm{kg}$ BW when it was needed and possible 7 . The initial dose for the test preparation used in 
this study was $300 \mathrm{mg} / \mathrm{kg}$ BW. According to the 423 procedures of the OECD Guideline, the initial dose for the test preparation was unknown, or there was no information related to its toxicity that was $300 \mathrm{mg} / \mathrm{kg} \mathrm{BW}$. The test preparation was administrated at an initial dose of 300 $\mathrm{mg} / \mathrm{kg} \mathrm{BW}$ to 3 tested animals per group. Upon the treatment with this dosage, no toxic symptoms and death signs were found in the experimental animals. The experiment was then continued at a dose of $2.000 \mathrm{mg} / \mathrm{kg} \mathrm{BW}$, and the condition of the experimental animals was reobserved. Up to 14 days after the treatment, there were no toxic symptoms and death signs in the experimental animals.

Table 1. The number of dead animals in the observation for 14 days after the administration of the test preparations at a dose of $300 \mathrm{mg} / \mathrm{kg} \mathrm{BW}$ and 2,000 mg/kg BW

\begin{tabular}{|c|c|c|c|c|c|c|}
\hline \multirow[t]{2}{*}{$\begin{array}{c}\text { Treatment } \\
\text { Group }\end{array}$} & \multirow[t]{2}{*}{$\begin{array}{l}\text { Number of } \\
\text { Early Rats }\end{array}$} & \multicolumn{2}{|c|}{$\begin{array}{l}\text { Number of Final } \\
\text { Rats, the dosage } \\
\text { of } 300 \mathrm{mg} / \mathrm{kg} \mathrm{BW}\end{array}$} & \multicolumn{2}{|c|}{$\begin{array}{l}\text { Number of Final } \\
\text { Rats, the dosage of } \\
2,000 \mathrm{mg} / \mathrm{kg} \mathrm{BW}\end{array}$} & \multirow[t]{2}{*}{$\begin{array}{c}\mathrm{LD}_{50} \mathrm{cut} \\
\text { off } \\
(\mathrm{mg} / \mathrm{kg} \\
\mathrm{BW})\end{array}$} \\
\hline & & Dead & Live & Dead & Live & \\
\hline Control & 3 & 0 & 3 & 0 & 3 & \\
\hline $\begin{array}{l}\text { Solvent } \\
\text { Control }\end{array}$ & 3 & 0 & 3 & 0 & 3 & \\
\hline $\begin{array}{l}\text { Gynura } \\
\text { Procumbens } \\
\text { extract }\end{array}$ & 3 & 0 & 3 & 0 & 3 & $>2,000$ \\
\hline $\begin{array}{l}\text { Azadirachta } \\
\text { indica extract }\end{array}$ & 3 & 0 & 3 & 0 & 3 & \\
\hline $\begin{array}{l}\text { Combination } \\
\text { extract of } \\
\text { both }\end{array}$ & 3 & 0 & 3 & 0 & 3 & \\
\hline Total & 15 & 0 & 3 & 0 & 3 & \\
\hline
\end{tabular}

Table 1 shows that administering the test preparation at a $300 \mathrm{mg} / \mathrm{kg}$ BW dose did not cause death in the experimental animals until the 14th day. Based on these results, the potential for acute toxicity or LD50 cut-off of the test preparation administered to female Wistar rats falls into category 5 or unclassified category?. The 423 procedures of the OECD Guideline were used to calculate the LD50 cut-off because this method was relatively simple; the number of experimental animals used was small, and the test results' validity was not inferior compared to other methods.
Observation of toxic symptoms is one of the qualitative measures of toxicity. Based on the observed toxic symptoms, it did not display any toxic symptoms appearing after treatment. Hence, it can be perceived that the test preparations administered either single or in combination between the extracts of Azadirachta Indica A. Juss. and Gynura procumbens (Lour.) Merr. were declared safe in terms of acute toxicity.

In the final stage, the experimental animals were sacrificed by means of neck 
dislocation. Prior to the surgery, rats' heart rate and breath were re-observed to ensure the experimental animal had actually died. Furthermore, the liver organ was taken. The reason for examining the liver is because the liver has various vital functions in the body, like neutralizing toxic substances, synthesizing serum protein, regulating nutrition and secreting bile salts ${ }^{9}$. The taken liver organs were then weighed and preserved in a 10\% formalin solution. Observation of the experimental animal organs was carried out macroscopically and microscopically. Macroscopic observations were employed to determine any visible damage to the organs due to the test's provision that did not appear visually when the experimental animal was still alive. Based on the results of macroscopic observations, no damage and abnormalities were found after treatment. Based on the vision, there was no difference between the organs of each group. Furthermore, organ weighing was carried out to determine the effect of treatment on the experimental animal organs seen from their weight. The average results of each treatment showed no significant difference from the experimental animals' organ weights.

Table 2. The weight of the experimental animal's liver

\begin{tabular}{|c|c|c|c|c|}
\hline No & Treatment & Rat & $\begin{array}{l}\text { Weight } \\
\text { (gram) }\end{array}$ & Average weight \\
\hline \multirow[t]{3}{*}{1} & Control & 1 & 5.6277 & \multirow{3}{*}{7.1289} \\
\hline & & 2 & 7.5499 & \\
\hline & & 3 & 8.2091 & \\
\hline \multirow[t]{3}{*}{2} & Solvent Control & 1 & 7.6987 & \multirow{3}{*}{$7 \cdot 3045$} \\
\hline & & 2 & 6.2049 & \\
\hline & & 3 & 8.0099 & \\
\hline \multirow[t]{3}{*}{3} & Gynura Procumbens extract & 1 & 10.3372 & \multirow{3}{*}{8.8553} \\
\hline & & 2 & 7.6726 & \\
\hline & & 3 & 8.5562 & \\
\hline \multirow[t]{3}{*}{4} & Azadirachta indica extract & 1 & 7.2171 & \multirow{3}{*}{$7 \cdot 4488$} \\
\hline & & 2 & 7.2091 & \\
\hline & & 3 & 7.9202 & \\
\hline \multirow[t]{3}{*}{5} & Combination extract of both & 1 & 5.6412 & \multirow{3}{*}{7.2778} \\
\hline & & 2 & 7.1454 & \\
\hline & & 3 & 9.0470 & \\
\hline
\end{tabular}

The formalin solution's liver organs were then transferred into histopathological preparations at the Pathology Laboratory of Balai Besar Veteriner, Wates, Yogyakarta. The dye used was Hematoxylin-Eosin (HE). HE is a common coloring compound used for cells and tissues. Hematoxylin would color the cell nucleus blue, while Eosin would color the cytoplasm and extracellular matrix red. The results of observations on the liver are as follows: 

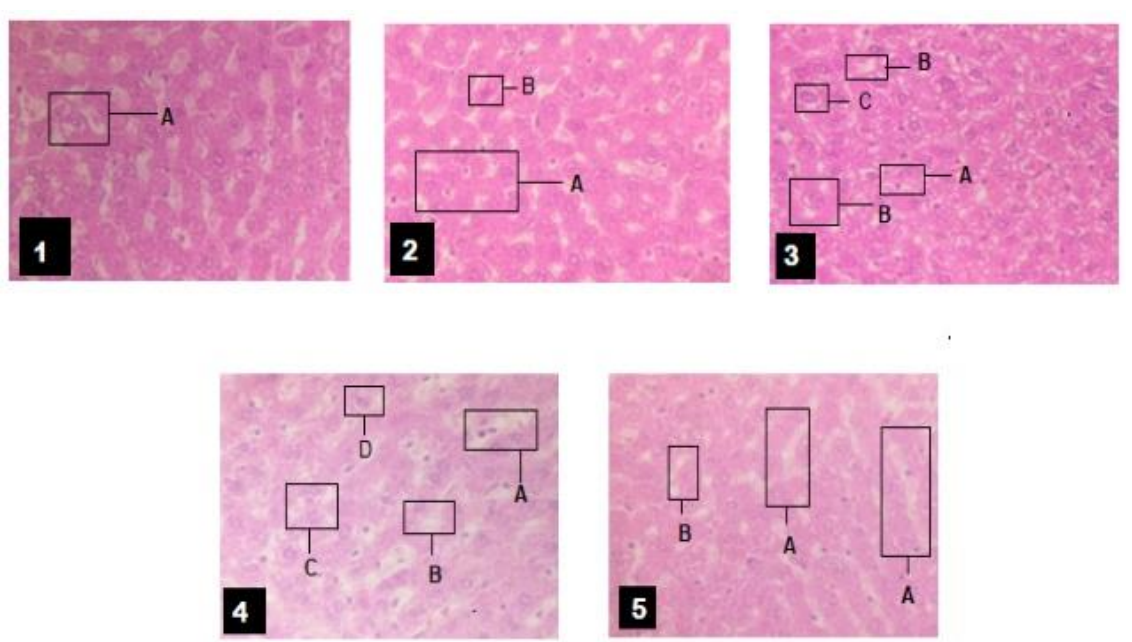

Figure 3. Histopathological microscopic profile of the rats' liver of the dosage of 2.000 $\mathrm{mg} / \mathrm{kg} \mathrm{BW}$

The histological profile of normal treated rats, namely the group of rats without administering the test preparation, includes A) The cell nucleus structure is located in the middle and shows a radial arrangement pattern. $(40 \times 10)$ (Figure 3.1). The histological profile of the solventtreated rats was a group of rats that were given distilled water and $0.5 \% \mathrm{Na}-\mathrm{CMC}$. A) The structure of the cell nucleus is located in the middle, B) Sinusoid ( $40 \times 10)$ (Figure 3.2). The rats' histological profile was treated with the ethanol extract of leaves of longevity spinach (Gynura procumbens (Lour.) Merr.). A) The nucleus is located in the center, B) Dilation of the central vein,
C) Sinusoid. $(40 \times 10)$ (Figure 3.3). Histological profile of rats treated with ethanol extract of neem leaves (Azadirachta Indica A. Juss.). A) The nucleus is located in the middle, B) Dilation of the central vein, C) Fat hepatocytes, D) Sinusoids $(40 \times 10)$ (Figure 3.4). Histological profile of rats treated with a combination of ethanol extracts of neem leaves (Azadirachta Indica A. Juss.) and leaves of longevity spinach (Gynura procumbens (Lour.) Merr.), A) Dilation of the central vein, B) Sinusoids $(40 \times 10)$ (Figure 3.5).

Table 2. The score of Hepatocyte Damage

\begin{tabular}{|c|c|c|c|c|c|}
\hline \multirow{2}{*}{ Test } & \multicolumn{4}{|c|}{ Hepatocyte Damage (\%) } & \multirow{2}{*}{ Total } \\
\hline & Normal & Inflammation & Degradation & Necrosis & \\
\hline Control & 60 & 0 & 0 & 0 & 60 \\
\hline Solvent Control & 52 & 0 & 0 & 0 & 52 \\
\hline $\begin{array}{l}\text { Gynura Procumbens } \\
\text { extract }\end{array}$ & 58 & 22 & 0 & 4 & 84 \\
\hline Azadirachta indica extract & 58 & 20 & 0 & 4 & 82 \\
\hline $\begin{array}{l}\text { Combination extract of } \\
\text { both }\end{array}$ & 58 & 14 & 0 & 8 & 80 \\
\hline
\end{tabular}

Determination of liver damage score is a modification of Manja Roenigk's scoring histopathology. The interpretation of the histological preparations on the liver organs of the experimental animals did not show any damage to the cells in the 
normal and solvent group. The control group showed the highest percentage of the normal cell than the other groups. In the group treated with the ethanol extract of Gynura procumbens (Lour.) Merr., there was no liver cell damage, indicating that there were only a few widenings of the central veins. It was probably due to the high content of flavonoids in the extract. In the group treated with the ethanol extract Azadirachta Indica A. Juss., it did not show any significant damage and only a few widenings of the central veins leading to inflammation, and a little fatty hepatocyte was shown as empty vacuoles in the cytoplasm of the liver cells. This fatty process was reversible and caused by an inhibited release of lipid transfer from inside cells and an imbalance in synthesis and the release of triglycerides carried by parenchyma cells into the circulation ${ }^{10}$. In the combination treatment group, Azadirachta Indica A. Juss's extract and leaves of Gynura procumbens (Lour.) Merr. was seen to widen the central vein. In all treatments except the normal treatment group, several sinusoids were indicated by the presence of a flat and dark cell nucleus with little cytoplasm.

In the experimental animals' liver cells, the possibility of necrosis was indicated by the destruction or loss of the nucleus (cell nucleus). However, the amount of necrosis found was not too much, and no tested animals had died during the treatment. Moreover, in general, there was no significant damage to the liver of the experimental animal. It was likely due to the presence of flavonoid and phenolic compounds in both extracts. Hence, these compounds can act as antioxidants that can minimize toxin compounds' harmful effects ${ }^{1}$.

\section{CONCLUSION}

The test compound of a combination of the ethanol extract of Azadirachta Indica A. Juss. and Gynura procumbens (Lour.) Merr. after acute toxicity test with the 423 procedures of OECD up to a dose of 2,000 $\mathrm{mg} / \mathrm{kg}$ BW did not show any death or signs of toxicity in the experimental animals; hence, the combined extract was categorized as unclassified category according to GHS.

\section{ACKNOWLEDGMENT}

We would like to thank the Faculty of Health, Jenderal Achmad Yani University Yogyakarta, for funding this research

\section{REFERENCES}

1. Pratama, N. P., Sari, K. R. P., Mutya, E. (2019). Effect of Azadirachta Indica A.Juss. and Gynura Procumbens (Merr.) Leaf Extract Combination Towards Free-Radical Scavenging Activity. International Journal of Advanced Research, 7(9), pp. 737-741.

2. Akowuah, G. A., Sadikun, A. \& Mariam, A. (2002). Flavonoid Identification and Hypoglycemic Studies of Butanol Fraction from Gynura procumbens. Pharmaceutical Biology, 40(6), pp. 405-410.

3. Sunarwidhi, A. L., Sudarsono, S., \& Nugroho, A. E. (2014). Hypoglicemic Effect of Combination of Azadirachta indica A. juss. And Gynura procumbens (Lour.) Merr. Ethanolic Extracts Standardized by Rutin and Quersetin in Alloxan-induced Hyperglycemic Rats. Advanced 
Pharmaceutical Bulletin, 4(2), pp. 613618.

4. Zhang, X. F., \& Tan, B. K. (2000). Effects of an Ethanolic Extract of Gynura procumbens on Serum Glucose, Cholesterol and Triglyceride Levels in Normal and Streptozotocininduced Diabetic Rats. Singapore Medical Journal, 41(1), pp. 9-13.

5. Pillai, N. R., \& Santhakumari, G. (1981). Hypoglycemic Activity of melia azadirachta Linn (neem), Indian Journal of Medical Research, 74, pp. 931-933.

6. Ngatidjan. (1997). Metode Laboratorium dalam Toksikologi. Yogyakarta: Pusat Antar Universitas Bioteknologi Universitas Gadjah Mada.

7. OECD. (2001). OECD Guideline 423 For Testing of Chemicals, Acute oral Toxicity-AcuteToxic Class Method. No. 423, OECD, Paris.

8. Balasz, T. (1970). Measurement of Acute Toxicity. Oxford and Edinburgh: Blackwell Scientific Publications.

9. Longo, D. L., Kasper, D. L., Jameson, J. L., Fauci, A. S., Loscalzo, J., \& Hauser, S. (2011). Harrison's Principles of Internal Medicine, 18th ed. New York: McGrawHill.

10. Francisco, J. S., Waldo, L., Garcia, J., Isadora, L., \& Karin, S. (2018). Histopathological and immunohistochemical characterisation of hepatic granulomas in Leishmania donovaniinfected BALB/C mice: a time-course study. Parasites Vector Journal, 11(73), pp. 1-9. 